\title{
Economic and technical considerations on potential recourses of Albania in textile natural fibers
}

\begin{abstract}
The paper's aim is to present some economic considerations on natural textile fibers, historically produced in Albania, based on their quality and feasibility. Natural textile fibers, traditionally produced in Albania are: sheep's and goat's wool, cotton, silk, hemp, flax and Spanish broom. Also, there were a short-lived and non-productive tentative in producing natural textile fibers from agave. The highest point in natural fibers production was the period 1950-1990, when Albania has developed a large textile industry based on natural fibers. However, for most of them cultivation and production has date long before, but them was aimed to export or for handicraft products (wool and flax from ancient times, cotton at least from $17^{\text {th }}$ century, silk from $16^{\text {th }}$ century and hemp from $1^{\text {st }}$ century). The world history of production and consuming of natural textile fibers has its ups and downs, especially after introducing the synthetic and regenerated fibers in the beginning of last century. Meanwhile, nowadays global demand of natural fibers is growing exponentially and global consuming of them has a new perspective due to their ability to be environmental and human friendly.
\end{abstract}

\author{
Volume 4 Issue 3 - 2018
}

Genti Guxho

Faculty and Head of the Textile and Fashion Department,

Polytechnic University of Tirana, Albania

Correspondence: Dr. Genti Guxho, Vice Dean of the Mechanical Engineering, Faculty and Head of the Textile and Fashion Department, Polytechnic University of Tirana, Sheshi “Nene Tereza" Nol Tirana, Albania, Tel +355688044575, Emailgguxhog@fim.edu.al

Received: March 21, 2018, 2017 | Published: May 07, 2018

Keywords: natural textile fibers, consumption of fibers, production of fibers, classification according quality, fiber price

\section{General consideration}

In Albania the hay day for the production of natural textile fibers intended for industry was during 1950-1990. However, for some of them we can say that cultivation had started long ago, and was intended for export or for local craft products (wool fiber and flax from ancient times, cotton since at least the $17^{\text {th }}$ century, silk fibres $16^{\text {th }}$ century, and hemp fibers $1^{\text {st }}$ century).

\section{Animal fibers}

Silk. Albania is among the European countries, which has cultivated and processed natural silk. Greater development of this industry has taken place between the 16 th century and the $19^{\text {th }}$, at which time its cultivation became a family tradition, for weaving fabrics, handcrafted clothes and for trade with neighbouring countries. ${ }^{1}$ In the following centuries the principal place of silkworm cultivation in Albania, was Shkodra. The variety of silk worms in the Shkodra area manifest great bio - technological value, so distinct from other varieties of Bombyx mori that now is known as "Seta Scutarina". ${ }^{2}$ During the last century $\left(20^{\text {th }}\right)$, natural silk production in Albania has experienced highs and lows: after World War I it dramatically decreased due to many factors, prebine epidemic ${ }^{3}$ and the introduction of artificial fibers, which tried to imitate silk. The second period is that after World War II until 1990, when the Albanian economy was concentrated in the hands of the state by reducing private silk production. The first State run Station had 5 silk production lines. Its role was scientific work and the production of $30 \mathrm{~kg}$ eggs each year of hybrids silkworms. A station for egg production of silk was built near the city of Tirana (Kërrabë). During the same period it was experimented with the growth of oak silk, which had inferior properties compared with mulberry silk. During this period were planted over 1million mulberry trees. The third period is that after 90years, when the silk industry was destroyed as a result of major political changes in Albania. In the last 20years there have been several attempts to re- optimize the industry but without success.

\section{Wool fibers}

Among raw textile materials that are produced in Albania, protein fibers (fibers of animal origin) are the earliest fibers produced and the ones most produced. This is due to:

a. Geographical position of Albania near to the growers and producers of the earliest products with fibers of animal origin. The multipurpose characteristics of animals farmed.

b. The irreplaceable and precious value of the fiber of animal origin in terms of quality and natural production limitations.

c. Specific characteristics of economic development. ${ }^{4}$

Distribution of races that are the source of woolen textile fibers is shown in Graph $1 \&$ Graph 2.

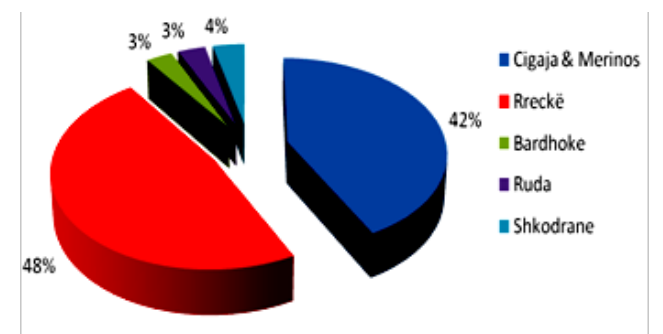

Graph 1 Sheep's breed distribution. ${ }^{4}$

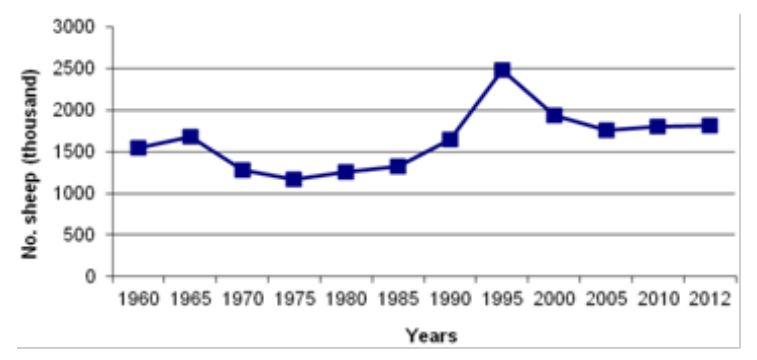

Graph 2 Number of sheep (thousand). ${ }^{5,6}$ 
While the production of wool fibers in Albania has increased after 1990, their quality has dropped, due to lack of destination. The number of livestock has increased and increasingly the structure of the races has changed because of their import. ${ }^{4}$ The sale price of wool fibers in the domestic market has shown a reverse tendency to that of the global market, as appears from the Graph $3 \&$ Graph 4.

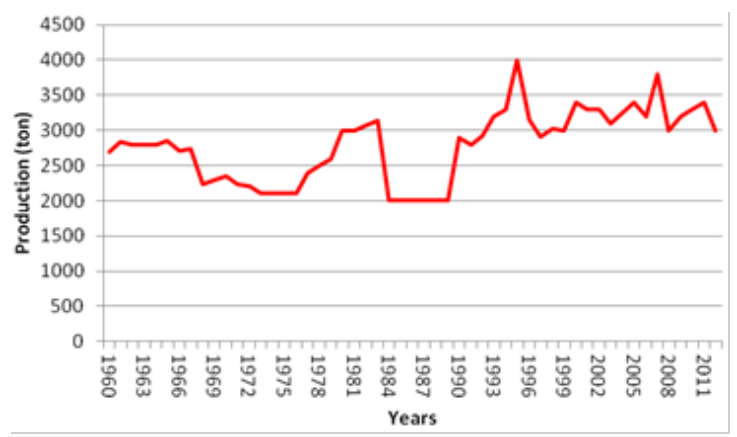

Graph 3 Wool production in Albania. ${ }^{5,6}$

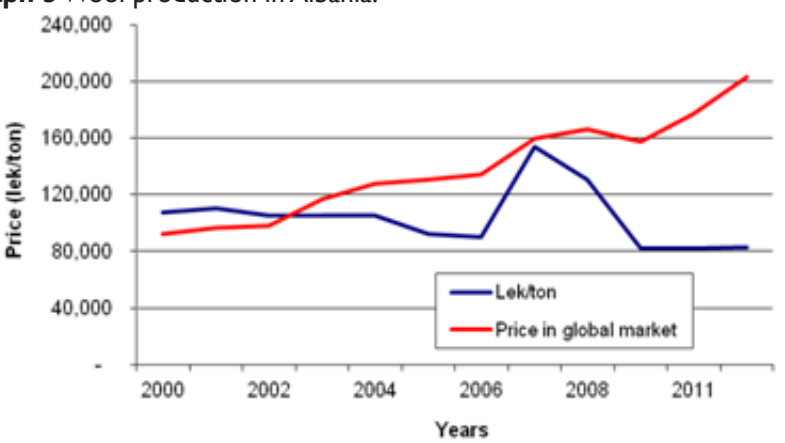

Graph 4 Price of wool in internal market and price's trend in global market. ${ }^{6}$

\section{Plant's fibers}

Cotton: Albania has cultivated cotton since at least the $17^{\text {th }}$ century. Tirana area has been renowned for the cultivation of this crop farmed in the period when the Albanian territories were part of the Ottoman Empire. Cotton continued to be cultivated in Albania, but to be perfectly honest this culture really developed after World War II. Albania's communist government with the help of the former USSR and later the People's Republic of China established a network for industrial processing of cotton fiber and cotton textile production or its mixtures with synthetic fiber. Tirana, Berat, Korça were major centres of industrial textiles and cotton fields in Myzeqe was the main area of cotton cultivation in Albania. The largest production of cotton in Albania was during the $1980 \mathrm{~s}$, and during the early $1960^{\mathrm{s}}$, Albania also exported cotton fibers. Albania due to the installation of large cotton processing factories was forced to import large quantities of cotton, often equal in weight to its annual output. Areas where cotton is cultivated in our country are: Vlora, Delvina, Berat, Durres, Tirana, and the largest manufacture has been Fier (Graph 5) (Graph 6). ${ }^{7}$

Spanish broom or spartium junceu: It has been known since antiquity for its use as a textile fiber. Cultivating broom for textile purposes has been concentrated in the Mediterranean basin, particularly in Albania, France, Greece, Spain and Italy. ${ }^{8}$ Larger studies to revitalize broom for textile production are concentrated in Italy, in the area of Arbëresh villages. It is widely cultivated in Albania. In Albania it grows mainly in Mediterranean forest and shrub areas (height up to about $700 \mathrm{~m}$ ) mainly in the western and southwestern regions. In the second half of the $20^{\text {th }}$ century in Saranda and Vlora there were factories producing ropes and rugs from the broom. However, with the introduction of synthetic fibers, as in Europe, there was a drop in interest for this plant. Unfortunately, today in these areas this plant is used only for the production of cleaning brooms. It grows wild in the hilly area of Saranda (Lukovë, Borsh, Nivicë, etc.)

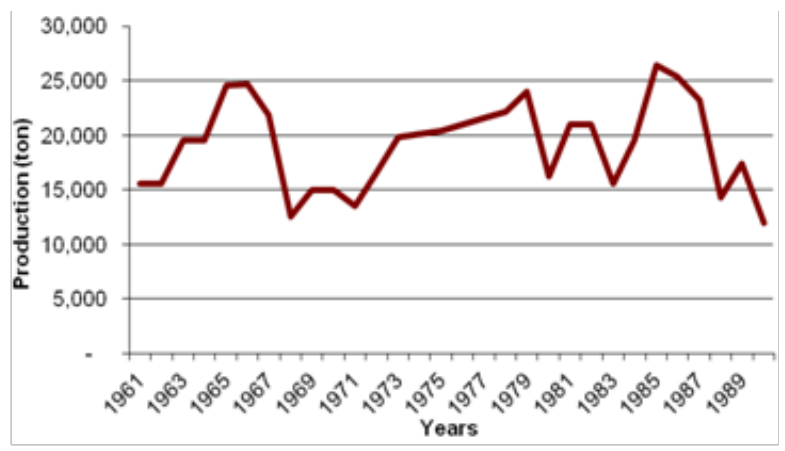

Graph 5 Cotton productions (ton) in Albania. ${ }^{6}$

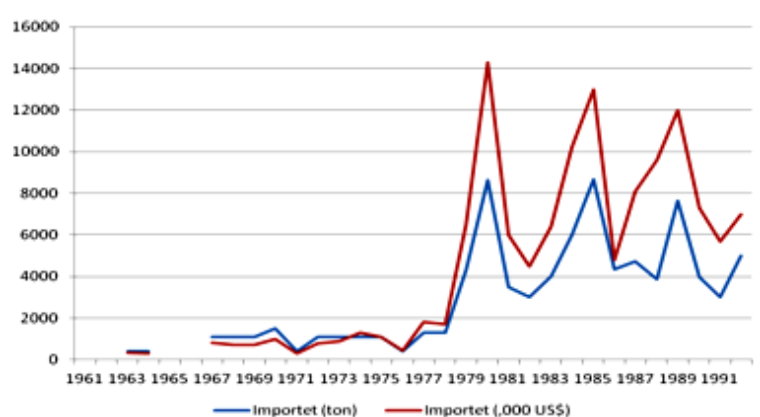

Graph 6 Imports of cotton in Albania. ${ }^{6}$

Hemp: Most industrial hemp for fiber and textiles nowadays is produced in China. Separation of fibers from steam (retting) is made in water, in order to better control the process and to produce high quality fiber. Unlike Spanish broom, hemp fibers require long preparation of the water that will be used separating them from the stem, in order to obtain fibers capable of producing high quality textiles. ${ }^{9}$ Albania, as part of the Balkan Peninsula, has been the subject of the spread of the hemp plant, from the $1^{\text {st }}$ century $\mathrm{BC}$. There are no accurate records on the use of the hemp plant in Albania but literature suggests that Albanians have been the first country in Europe to be aware of the hemp plant and it is part of their indigenous linguistics. As part of Roman culture, of course, today's settlements in Albania have known the manifold uses of the hemp plant and have used them. It has been documented that hemp textile fiber was available in Albania on the $14^{\text {th }}-15^{\text {th }}$ century. ${ }^{10}$ Albania established the first factory processing industrial hemp in 1946.This factory was destined for processing Spanish broom and hemp, for the production of ropes. ${ }^{9}$

Flax or linum usitatissimum: It is used in Albania since prehistorically times (around 3500BC). The use of flax since ancient times has caused for other similar cotton and silk products to be referred to by that name. Together with hemp it was used throughout the $20^{\text {th }}$ century for the production of ropes.

Agave: In the southern coast of Albania (mainly in the limestone 
cliffs of the Vlora and Saranda areas) in the area of the Mediterranean shrubs, endemic plants of the Agave americana has been cultivated for industrial intentions, in fact, the Agave americana was cultivated in Albania for experimental purposes during 1970-1980 for the production of rope. Although now there is little, if any interest in the industrial sense, this plant has survived and has won in the rivalry with other native plants. From year 2009 the Albanian government does not allow the entry of Agave americana plants in Albania and are considered as invasive plants.

\section{Study method}

The economic evaluation is based on the data of potential production prior to the year 1990 and the qualitative characteristics of the fibers according to the latest Albanian studies. The study of economic value is focused on income that could have been accumulated from the direct sale of the products in the world market without analyzing profits that the industrial processing in the native market or the production costs. For both variables it has been thought that they would simply bring advantages for Albania through income benefits from its sale in global markets. The experimental results have been used to classify by quality of the fibers produced in Albania and to set a real correlation with the global market value.

\section{Experimental results}

The experimental results were obtained from recent studies conducted for classification of quality of domestic textile fibers. The exception is cotton, for which the date prior to 1990 was used. Table 1 gives some valuable features for classifying the quality of fibers produced in our country. ${ }^{11-13}$

Qualitative characteristics of the fibers produced in our country are such that make their production competitive in the global market. According to the data in Table1, the wool fibers can be classified into cross breed average (medium crossbred), silk is the middle class and low specificity and cotton has average length.

Table I Properties of natural textile fibers produced in Albania

\begin{tabular}{lllllll}
\hline Fibers & Finesses $(\boldsymbol{\mu m})$ & Finesses (number) & Length $(\mathbf{m m})$ & Tensile strength cN & Tenacity G/tex & Ref. \\
\hline Wool & $27.5-32.5$ & & $100-250$ & & $9-18$ & $14-16$ \\
Silk & $20-32$ & $21-50 \mathrm{den}$ & Filament & $60-150$ & $22-46$ & 1 \\
Spanish broom & $30-34$ & & $\left.300-1000\left(47^{*}\right)\right)$ & $12-14$ & 18 & 17 \\
Hemp & & 2.32 tex & $20-22$ & & $32-67$ & 13 \\
Flax & & & $3-4$ & $16-60$ & 18 \\
Cotton & & $\mathrm{N}_{\mathrm{m}} 5000-7000$ & $>30 \mathrm{~mm}$ & 19 & 19 \\
\hline
\end{tabular}

*) individual fibers

\section{Economic evaluation}

In assessing the economic impact we will rely mainly on the average selling prices of natural fib textiles in the global market (Table 2).

Table 2 Current prices in global market of fibers under consideration ${ }^{6}$

\begin{tabular}{lll}
\hline Fibers & Price \$/ton & Variance (s) \$/ton \\
\hline Cotton & 2001.8 & 1286 \\
Hemp*) & 754 & 101 \\
Wool & 1993.6 & 1512.8 \\
Silk & 7061.72 & 7158.55 \\
Flax & 601.6 & 95 \\
Agave & 325 & 44 \\
\hline
\end{tabular}

*) Price is given for European short industrial

Just as prices and production of natural fibers in the world has experienced fluctuations arising from factors that do not always relate to the market (eg. weather conditions). Graph 7 gives the global production of natural fibers. In the economic evaluation the most important factor is the quality classification of fibers. Classification and fiber test results directly lead to a price corresponding structure (Graph 8). ${ }^{20}$

Evaluation of fiber production in Albania is based on the most optimistic scenarios in years, avoiding the analysis of natural factors and socio - economic factors (Graph 9) (Graph 10). However, this simplified analysis can give us an estimate if the revitalization of textile fiber production in our country is to be achieved (Table 3 ).

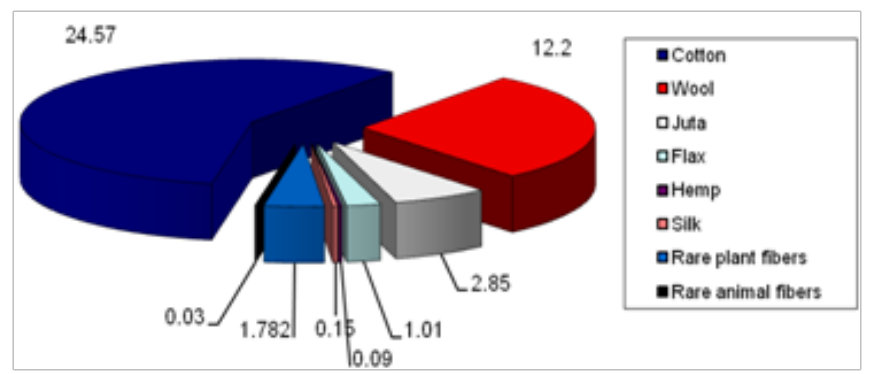

Graph 7 Global production of natural textile fibers (mln ton). ${ }^{6}$

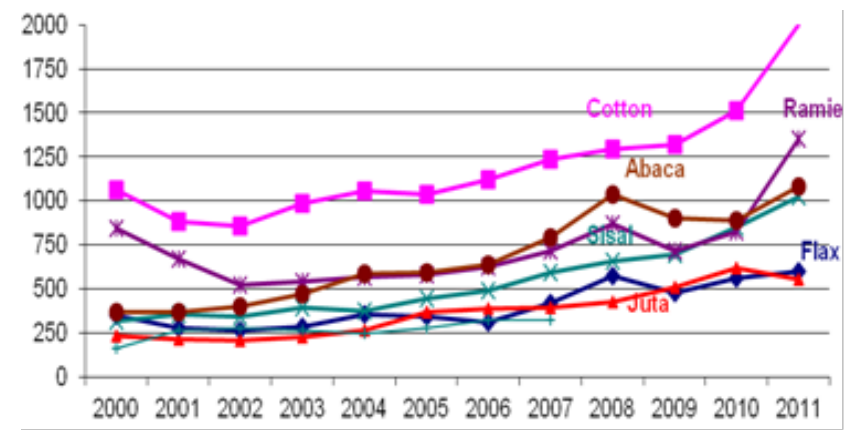

Graph 8 Variance of prices of plant fibers $(\$ /$ ton $){ }^{6}$ 


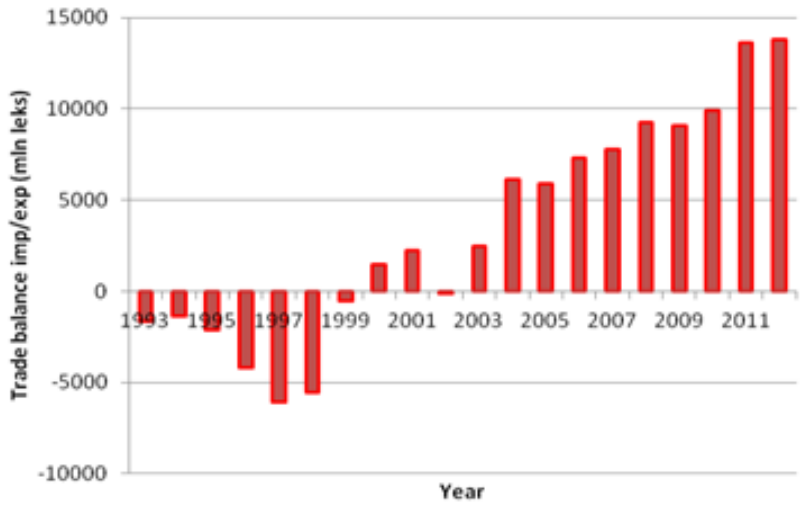

Graph 9 Variance of prices of animal fibers (\$/ton). ${ }^{6}$

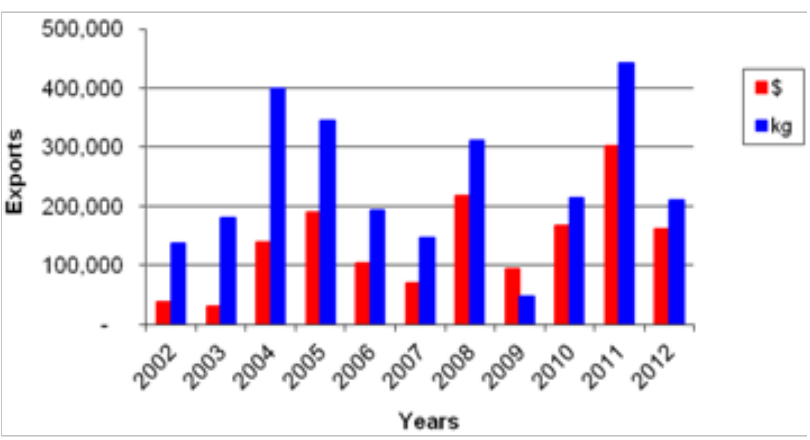

Graph 10 Trade balance of Albania for "textile and footwear" (mln leks).

Table 3 Potential production of natural textile fibers in Albania

\begin{tabular}{llll}
\hline Fibers & Production (ton) & Price USD/ton & Value USD \\
\hline Cotton & $25,350(1985)$ & 2001 & $50,725,350$ \\
Wool & $4,000(1995)$ & 1993.6 & $7,974,400$ \\
Silk & 500 & 7061.7 & $3,530,850$ \\
Spanish & $\left.3,000^{*}\right)$ & $\left.4098^{* *}\right)$ & $1,227,000$ \\
Broom & $2,500 *)$ & 754 & $1,885,000$ \\
Hemp & $1,500 *)$ & 325 & 487,500 \\
Agave & $2,200 *)$ & 601.6 & $1,323,520$ \\
Flax & & & $67,153,620$ \\
Total & & &
\end{tabular}

Among the fibers produced in Albania we can especially mention wool fibers, which are still produced in large quantities. For all natural fibers the data used is the one in the best year of production.

In terms of foreign trade Albania has a negative balance, which has been softened over the last 3-4years. One of the major contributors to alleviate the negative balance of foreign trade in Albania is the group of goods "Textile and footwear". Albania's trade balance is covered only by about $40-45 \%$ and one of the priorities of government policies is the alleviation of the negative balance. The group of goods "Textile and footwear" exports ( including textile raw materials), not only has undergone dramatic increase in exports over the last decade, but is the only positive voice of the balance at least since 2004 onwards with steady growth trend.

If we examine the current values of exports of fibers in more detail (HS ${ }^{1}$ 50, 51, 52 dhe 53), as an alternative to understand the levels of production of natural fibers in our country, we notice that exports in the last 10-12years have hit these peaks: for wool fibers in 2011 with about 437 tons $(3,400$ tons from the total production was in 2011), the silk fibers in 2004 with 32tons of vegetable fibers and blast fibers (plant fibers without cotton) in 2005, 28tons. In the absence of a processing industry in the country, it seems that the production of natural fibers available for textile industry in Albania is almost deserted. The annual value of exports of natural fiber textiles in good years is about $\$ 400.000$ or only $0.13 \%$ of Albania's exports in the "textile" (Graph 11) (Graph 12).

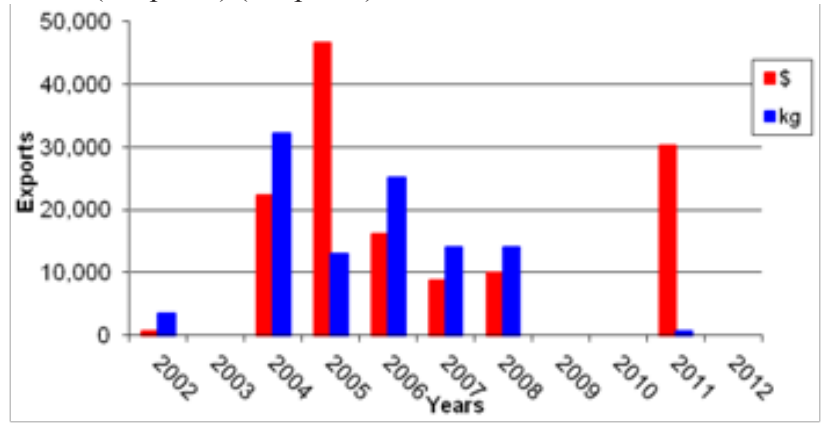

Graph I I Exports of wool fibers (in USD and in kg). ${ }^{21}$

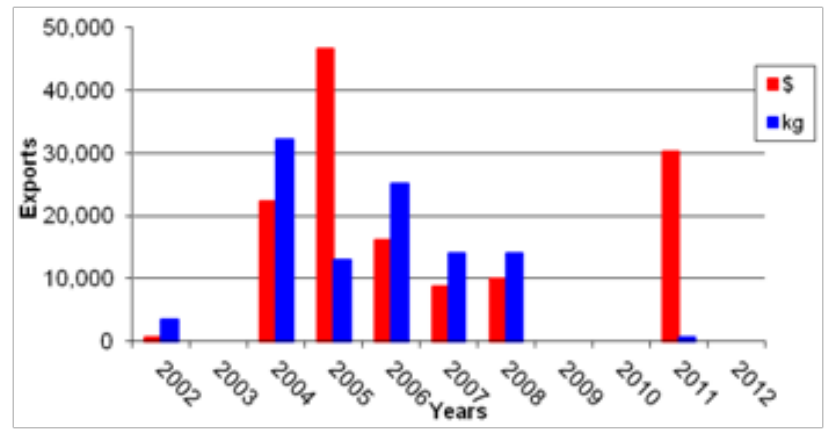

Graph 12 Exports of silk fibers (in USD and in $\mathrm{kg}$ ). ${ }^{21}$

Likewise, the area planted with vegetable fibers has fallen drastically, especially after 1990. Meanwhile, in Albania, about 200,000 hectares of agricultural land are unused, data by INSTAT (Graph 13) (Graph 14).

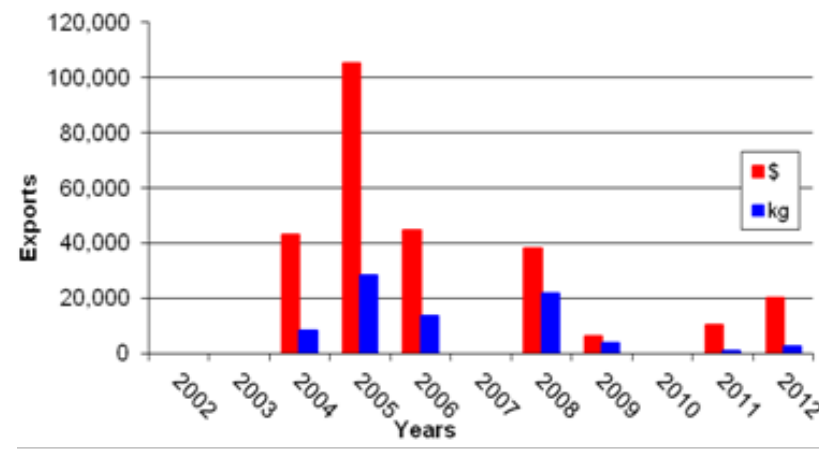

Graph 13 Exports of blast fibers (in USD and $\mathrm{kg}$ ). ${ }^{21}$

${ }^{1} \mathrm{HS}-$ Harmonized System. of tariff nomenclature is an internationally standardized system of names and numbers to classify traded products. It came into effect in 1988 and has since been developed and maintained by the World Customs Organization (WCO). 


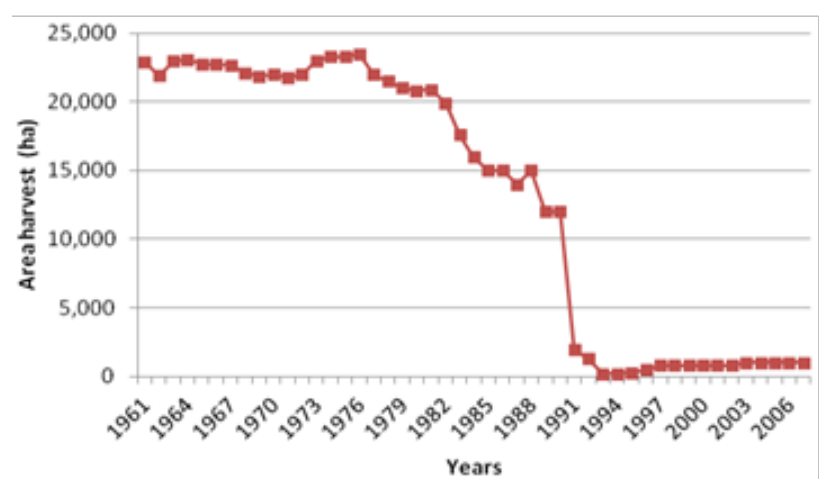

Graph 14 Area harvest used for natural plant fibers. ${ }^{21}$

Value added in export, if using the potential of production of natural raw materials, and if they will not be processed in the country, is around $10 \%$. If so, there would a fivefold improvement in Albania's trade balance in the "textile" area and it would soften the negative overall trade balance by 20\% (Table 3) (Graph 15) (Graph 16). But, beyond direct revenue, the development of this sector, of manufacturing natural textile raw materials would have important implications for employment and environmental protection. Similarly, the production of natural textile fibers associated with additional benefits of raw paper industry (the case of fibers of plant origin) and in some cases other additional raw materials for the pharmaceutical industry and cosmetics.

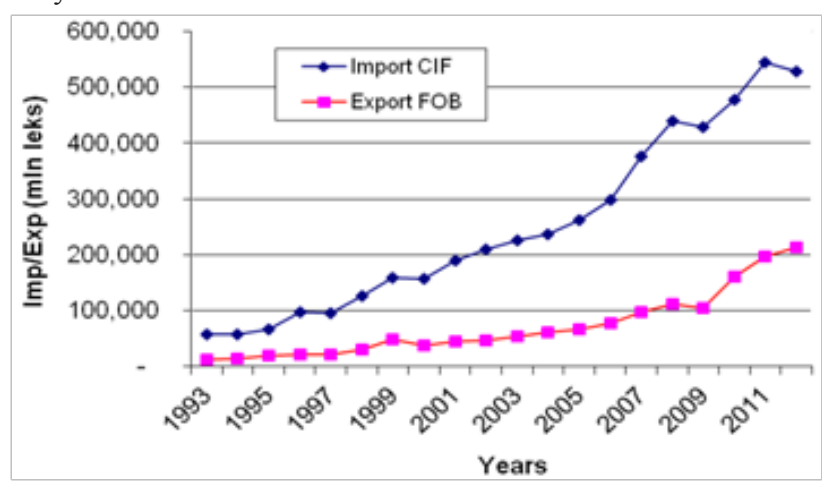

Graph 15 Albanian imports - exports mln leks. ${ }^{21,22}$

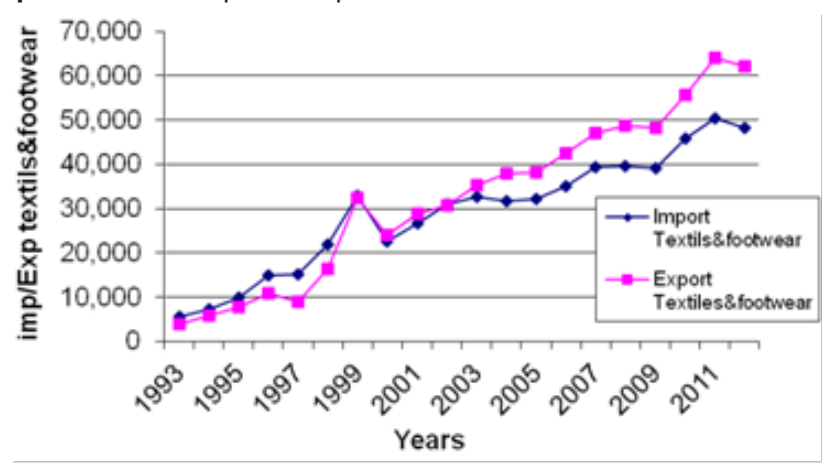

Graph 16 Albanian imports - exports in textile and footwear. ${ }^{21,22}$ Conclusion

Production of textile fibers in Albania has a long history, which has been conditioned by its geographical position as a country with Mediterranean climate and being nearby many larger centers of textile production in the world. This production has seen significant fluctuations as anywhere in the world. Natural textile fibers produced in Albania have qualitative characteristics suitable for industrial processing, as can be verified by laboratory data.

Textile Industry as an important contributor to the economy of the country and since it occupies first place in Albania's industrial exports, would have more opportunities to increase exports and production through a closed cycle if it was served from domestic raw materials. This would boost the possibility of increasing added value that Albania offers to the global market and stop/end a labor exporting economy. At the same time, it will decrease the percentage it coverage in the import/ export balance, in a sector with such a significant positive trend.

The above analysis does not take into account the possibility, potentially large, of processing these raw materials and then export them to add a value even greater. Moreover, the structure of exports of manufactured goods to Albania remains rigid and stuck mainly in textiles and footwear, while the food industry sectors and metalworking have no essential importance, ${ }^{23}$ although it may be based on local raw materials. Likewise, it becomes even more important if we consider that more and more in the structure of exported manufactured goods, we see an increase in paper, ${ }^{23}$ the raw material for fiber which can be not only from pulp timber.

The ability of bio - degradation and in most cases better mechanical characteristics than glass or carbon fibers create a significant advantage for natural fibers not only in textiles, but also in technical textiles and composite (used as the reinforcement material in matrix).

Revival of textile fiber production in our country would have an effect on the production of raw materials for export or for domestic industrial processing. In the world we see a trend for the revitalization of natural fibers, which may have lost ground due to the cheap price of synthetic fibers, economic exigencies, policy development etc. Today naturally, along with care for the environment and limited resources for the petrochemical industry that produces synthetic fibers, attention was turned to natural fibers and Albania can make a quick comeback to the production of natural fibers and with a colossal benefit not only economic one.

\section{Acknowledgements}

None.

\section{Conflict of interest}

Author declares there is no conflict of interest in publishing the article.

\section{References}

1. Xhoxhi A, Bejtja T. Silkworm Growth. Tirana: Publication of the High Agricultural Institute; 1983.

2. Guxho G. What We Need to Know About Luxury Fiber. Tirana: Publishing House Kristalina; 2012. 137 p.

3. Xhoxhi. A. Natural Silk Culture II. Tirana: House of Agricultural Propaganda; 1988.3 p.

4. Guxho G. Evaluation of physical-mechanical properties of animal fibers of animal origin from the local (Albanian) race as a determinant of their technological potential: dissertation for obtaining the scientific degree "Doctor". 2007. 
5. Instat. Albania in Figures 2012. Tirana; 2013.

6. FAO. Statistics Division 2014. Food and Agriculture Organization of the United Nation.

7. Biba O. Winding of cotton 1. Tirana; 1974.

8. GANTT Project. Broom, Art, Nature and Textile Technology. 2008.

9. Guxho G. Cannabis or Hippopotamus. Tirana: Edlora Publishing House, 2012: 69-96.

10. Gjergji A. Data on the garment in Albania in the XIV-XV centuries. Historical studies. 1967;4.

11. Zohary D, Hopf M. Oil and fiber crops. In: Weiss E, editor. Domestication of Plants in the Old World, The Origin and Spread of Cultivated Plants in West Asia, Europe, and the Nile Valley. Oxford: Clarendon Press; 1993. 279 p.

12. Report Integrated Coastal Zone Management and Purification Project Report. Association for the Conservation of Birds and Mammals of Albania. 2009

13. Guxho G. Experimental Results of Certain Characteristics of Hemp Textile Fibers in Albania. Tirana: UPT Technical Research Bulletin; 2014.
14. Guxho G. Classification according to the thickness of wool fibers from Albanian breeds. J Natural \& Technical Sciences. 2006;1(2):213.

15. Guxho G, Shehu Y, Nika V. Experimental study of the length of local protein fiber fibers. Technical Bulletin; 2009.

16. Guxho G, Shehu Y, Nika V. Experimental assessment of the physical characteristics of the protein (protein and fibrous fiber) from Albanian breeds. Albanian J Natural \& Technical Sciences. 2009;2:3.

17. Kaja P. Workshop: Gjineshtra. Textile department, Tirana: University of Tirana; 1988.

18. Baholli T. Physics Textiles. Tirana: University of Tirana; 1985.

19. Babo A. Cotton Culture. Tirana: Naim Frashëri; 1963.

20. Jörg Müssig. Industrial Applications of Natural Fibers Structure. Properties and Technical Applications. John Wiley \& Sons Ltd; 2010. $560 \mathrm{p}$.

21. http://data.un.org/Data.aspx?d=ComTrade.

22. Instat. The performance of foreign trade. Tirana; 2013.

23. ACIT. Albania 2008 Trade Report. Albanian Center for Competitiveness and International Trade; 2009. 